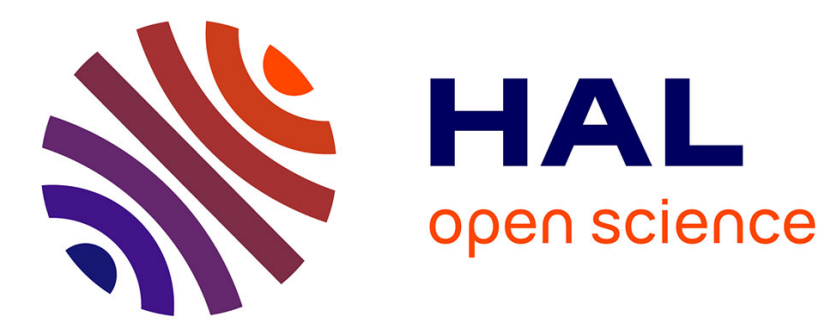

\title{
Commercial Vehicle Production Flexibility Factors
}

Luis De Oliveira Nascimento, Jorge Muniz Jr., Henrique Martins Rocha

\section{To cite this version:}

Luis De Oliveira Nascimento, Jorge Muniz Jr., Henrique Martins Rocha. Commercial Vehicle Production Flexibility Factors. IFIP International Conference on Advances in Production Management Systems (APMS), Sep 2016, Iguassu Falls, Brazil. pp.952-958, 10.1007/978-3-319-51133-7_112 . hal01615743

\section{HAL Id: hal-01615743 \\ https://hal.inria.fr/hal-01615743}

Submitted on 12 Oct 2017

HAL is a multi-disciplinary open access archive for the deposit and dissemination of scientific research documents, whether they are published or not. The documents may come from teaching and research institutions in France or abroad, or from public or private research centers.
L'archive ouverte pluridisciplinaire HAL, est destinée au dépôt et à la diffusion de documents scientifiques de niveau recherche, publiés ou non, émanant des établissements d'enseignement et de recherche français ou étrangers, des laboratoires publics ou privés. 


\title{
Commercial Vehicle Production Flexibility Factors
}

\author{
Luis de Oliveira Nascimento ${ }^{1}$, Jorge Muniz Junior ${ }^{1}$, and Henrique Martins \\ Rocha $^{2}$ \\ 1 Paulista State University, Guaratinguetá, Brazil \\ prof.henrique_rocha@yahoo.com.br \\ 2 Rio de Janeiro State University, Resende, Brazil
}

\begin{abstract}
In the competitive commercial vehicles market, new products are developed continuously in order to attend specific demands and surplus complexity is incorporated gradually to the manufacturing assembly plants. In this context, it is mandatory that the manufacturers enable a high flexibility production level to attend specific demands with low costs and agility. This paper aims to analyze factors that influence the flexibility of commercial vehicles production and to propose a prioritization model for industrial productivity enablement projects, in order to improve the production flexibility in a trucks and buses assembly plant. Managers and technical staff of a commercial vehicles production plant (88 professionals) were interviewed and data analyzed by Incomplete Pairwise Comparison (IPC), a multicriteria decision method. Results lead the company to implement lean office projects, which created the condition to reduce $30 \%$ in the firm horizon of order placement, reducing the time-to-market and leading customer to have a higher product valueadded perception, levering company's service level and competitiveness.
\end{abstract}

Keywords: Flexibility · Lean · Agility · Decision making.

\section{Introduction}

This work aims to analyze factors influencing the flexibility of the production of commercial vehicles and propose a prioritization model for industrial productivity enablement projects. The research was performed in a truck \& bus manufacturing plant located in Brazil, which produces vehicles in high-volume/high variety operation under a production concept model in which the suppliers interact directly on the final product assembly line, sharing physical space, responsibilities, and standard control [1].

According to Sheffi [2], organizations are threatened by short product cycles and subglobal supply chains, putting them under pressure to develop a greater capacity to confront risk with some resilience.

In this context, the automotive industry is offering wide range of products, but new models generally require new parts, which in turn, are incorporated and managed in the supply chain, along with parts of vehicles already underway. 
In the commercial vehicle sector, i.e.: trucks and buses, the scenario is even more challenging: such market is characterized by high-volume production and high variety, delivering vehicles customized for specific applications, levering the manufacturing operation complexity up to uncontrollable levels.

Naga and Kodali [3] state that the complexity of automotive industry models corresponds to the variety in which the production system is based on the quantity of different platforms, bodies and models produced in their assembly lines. By the other side, complexity of components is caused by the existence of optional features offered to customers, but mainly the impact of product development and supply chain boundary conditions, i.e., one of the factor that causes complexity in carmakers' manufacturing and supply chain systems is the number of pieces combinations and its management.

Modrak, Marton, and Bednar [4] correlate the growth of complexity with performance decrease. Their study indicates that larger variety of products in an automotive plant, higher the effort to deliver high-quality products at the desired time and at low cost.

Slack [5] suggests flexibility as solution for demands of quick responses and product variety in a fierce competition scenario, allowing high-performance manufacturing, with reliability, speed, and low costs. Flexibility results in better design and products developed in competitive contexts with high levels of uncertainty [6].

For those involved on tight schedules, consumer preference constant changes, and high uncertainty, manufacturing flexibility is not only desirable, but also a requirement for organizational survival $[7,8,9,10]$.

Therefore, a question that emerges in this context is: How to evaluate the choice of relevant projects to improve flexibility in the production of commercial vehicles? How to prioritize these improvement projects forward the interests of different areas? There is a need for development of a model to rank and prioritize productivity improvement projects, considering lean thinking, agility, and mass customization, to support company's managerial decisions.

The next paper sections are as follows: Section "Theoretical Background" comprises the fundamentals of Lean production \& Lean administration, Agility, Flexibility, and Mass Customization; Section "Procedures and Techniques" presents the research methodology; Section "Results and discussion" highlights the research results and findings. Finally, at the Section "Conclusions and Remarks", findings are assessed and discussed, while proposals for additional researches are made.

\section{Theoretical Background}

The concepts of Lean Thinking, Flexibility, Agility, and Mass Customization are discussed in this topic, while some related literature is also referenced.

Holweg [11] states that the Lean Thinking changed the paradigms of mass production, helped to change the relationship between the automobile industry 
productivity and quality and created a new way of thinking about operations, focused on waste source detection and elimination.

Intriguingly, Baines et al. [12] claim that Toyota's Lean manufacturing system is actually an extension of their product development philosophy and not the reverse, but most western manufacturers are focusing their Lean initiatives at operations with few attempts to adopt Lean in design-related activities, what could explain why all too often lean projects add little or no value, even though similar methods work very well at Toyota. Qudrat-Ullah, Seong, and Mills [13] stated that the Lean product development process can successfully be applied to improve the operations of a high variable-low volume product mix business.

Gupta and Buzacott [14] define flexibility as the property to be capable of responding or conforming to changing or new situations. Needs that lead to flexibility are, as per Kara and Kayis [15], related to the market (demand variability, short life cycle of products and technologies, great product variety, increased customization, and reduced delivery times) and/or related to the manufacture process (uncertainties in relation to machines and material in processes shortfalls, change in the delivery time of raw materials, and manpower variations).

Agarwal et al. [16] define agility as the ability of companies to cope with the uncertainties of the market and deliver goods and services with high level of service, concept which is directly related to flexibility and process speed.

Boyton, Victor \& Pine II [17] define Mass Customization (MC) as the capacity to produce product variety rapidly and inexpensively, in direct contradiction of the assumption that cost and variety are tradeoffs. MC refers to fast, low cost, and varied production companies, fulfilling a large proportion of consumers through a large variety of products and innovations. As a result, organizations increase process efficiencies in clearly conditions of stable process change.

The concept of mass customization can be approached as a development strategy and production boosted primarily by sales teams and marketing that are in contact with the demands of customized products, bringing and discussing the information for development teams and production enterprises. MC goal is to create individually customized products, with mass production volumes, costs and competitive efficiencies [18].

\section{Procedures and Techniques}

The methodology used to carry out the present research went through the steps listed below, along an eight-month period (Jul/2015-Mar/2016):

1. Literature analysis, encompassing the conceptual basis of Lean Thinking, Lean Manufacturing, Lean Administration/Lean Office, Flexibility, Agility, and Mass Customization;

2. Research planning and managerial granting, i.e., data collection processes; identification of people to be interviewed, questionnaire development, research proposal submission, negotiation and approval; data analysis and results screening, etc. 
3. Semistructured interviews with selected executive managers/directors involved to Operations (Production \& Logistics, Quality, Finance, Information Technology, and Sales, Marketing \& After-sales), having the following open-ended questions as an interview basis (C1 questionnaire): How does the company materials' planning process work?; Is a reduction in production planning horizon feasible? Which are the opportunities and impacts? Would it impact flexibility? Would it cause any impact on costs?; Is a reduction in purchase order planning horizon feasible? Which are the opportunities and impacts? Would it impact flexibility? Would it cause any impact on costs?; What would be the impact to reduce waste and make the supply chain lean?

4. Interview content compilation, through a content analysis process, in order to get the understanding about the complexity/flexibility managerial perceptions and decisions, and also to identify elements that affect vehicles production flexibility, which were, then, classified as "dimensions" or "factors";

5. Those elements and their classification were used to develop a closed-ended questionnaire (C2 questionnaire), purposed to validate such elements and to identify correlations among them. This step aims to get a project prioritization matrix to be used by the studied company to establish an implementation plan for production flexibility improvement high-impact projects.

The questions were base on level of importance pair comparisons between elements: each element was compared with each other and respondents would rate them in a 1-9 scale, being: (1) same importance; (3) low importance; (5) mid importance; (7) high importance; and (9) extreme importance;

1. The electronic questionnaire/spreadsheet was presented to the senior executives and, after that, deployed to their staff members, a total of 158 people. 88 responses (55.7\%) were received: one $\mathrm{VP}$, six executive managers, ten managers, 20 supervisors, one specialist, one coordinator, and 49 technical staff/engineers;

2. Data was analyzed to rank elements based on respondent perception through Incomplete Pairwise Comparison (IPC), a variation of the Analytic Hierarchy Process (AHP), multicriteria decision method, which allows the comparison of pairs of factors and sort them by relevance, allowing decision-making based on responses that keep the accuracy of the results [19]; and

3. Results from the IPC step were used to define the scope of planning and execution of the suggested projects for flexibility alternatives as a pilot project. The execution of such project would provide a feedback in regards to production flexibility variance through lean thinking.

\section{Results and Discussion}

Out of the $\mathrm{C} 1$ questionnaire, the following elements that affect vehicles production flexibility were identified (Figure 1): 


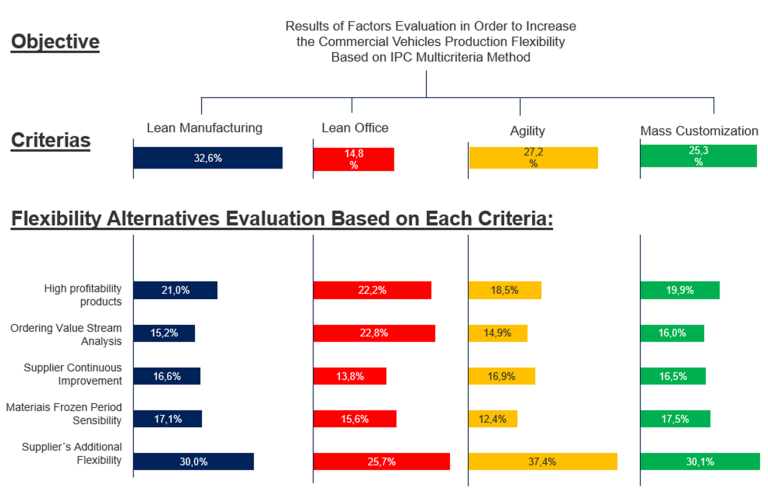

Fig. 1. Out of the C1 questionnaire

- Factors: Lean Manufacturing (32.6\%), Agility (27.2\%), Mass Customization $(25.3 \%)$, and Lean Office (14.8\%).

- Manufacturing flexibility: supplier's additional flexibility (FAS), materials frozen sensitivity analysis (ASF) and supplier continuous improvement (MCF).

- Materials ordering flexibility: ordering value stream analysis (VSM) and high-profitability products (PAL).

Those elements were used to feed the $\mathrm{C} 2$ questionnaire and, then, applied, as described in the previous section. For further detailing, Nascimentos's [20] dissertation shall be accessed.

From such analysis, the following elements were selected/validated: FAS (31.4\%), PAL (20.2\%), VSM (16.5\%), MCF (16.2\%), and ASF (15.7\%). However, in regards to project prioritization, the sequence and level of agreement were different: MCF (29\%), VSM (27\%), FAS (23\%), ASF (20\%), and PAL (1\%). Breaking them down, the following lean thinking projects were proposed and submitted for appraisal: (1) Make Product Development Faster; (2) Reduce Ordering Lead Time; and (3) Increase Administrative Service Level.

As it can be seen, project implementation priority is related to administrative/managerial activities, therefore, related to lean office (a.k.a. lean administration). Upon discussion, it was detected that even though the lean office factor had lower priority when compared with lean manufacturing, agility, and mass customization, such response conflicts with proposed projects' prioritization. Lean office low priority can be understood by the fact that the major focus has, so far, been given to increase value-added value in production environment.

Based on that assumption, the choice to pursue an implementation based on the research's results was the lean office application project, contained in the analysis of alternative applications of value stream. The rationale to such choice was: (1) several lean production projects were/are developed in the studied company since 2008: therefore, it is a known subject and results have proved their effectiveness. Besides that, the principles of agility are also present in the 
organization by focusing service tailored to customer needs, the pursuit of satisfaction in specific niches, resulting in time reduction activities, mainly in its supply chain. The mass customization was recently implemented in product development; and (2) the studied company had never tried to analyze/implement lean office techniques.

Implementation counted with the support of Shingijutsu Global Consulting (SGC), a global company specializing in performance increase efficiency in manufacturing, logistics and processes. SGC consultants attended to three kaizen events focused on logistics, production, and administrative processes, in which former performance jeopardizing the company competitiveness.

The results obtained with the implementation of the mapped improvements, discussed with the team and moderated by SGC consultants created the conditions to reduce $30 \%$ the firm horizon of order placement, reducing the time-tomarket and leading customer to have a higher product value-added perception, levering company's service level and competitiveness.

\section{Final Considerations}

The research highlighted the importance of lean manufacturing factors, speed, mass customization, and lean office to improve the flexibility. It also established a model for productivity enablement projects ratting and prioritization, based on managers and technical staff perception.

Even though the company started lean implementation in 2008, it was, since then, focused on manufacturing activities. The initiation of lean office approach has proven to be able to unveil hidden waste-avoidance opportunities, uplifting performance in time-to-market, reducing overall manufacturing throughput time and planning horizon, which levered production flexibility.

Even though results are preliminary (complete implementation is still ongoing), favorable impacts are already perceived by senior managers. Future researches are to monitor results from now on and, upon adhering to actual trend, should be applied to other products and plants.

\section{Acknowledgement}

The authors thank for efforts referees during the revision process and comments. Also, we thanks the Brazilian National Research Council (CNPq), which supported this study with the Productivity Grants (Proc. 309028/2015-9).

\section{References}

1. Maitan Filho, P.L., Simoes, J.M.: Estruturas Organizacionais e Indústria Automobilística: Os Desafios e Contradições de um Setor em Transformações. Revista Uniabeu 8(18), 114-128 (2015)

2. Sheffi, Y.: Building a Resilient Supply Chain. Harvard Business Review pp. 1-4 (2005) 
3. Jasti, N.V.K., Kodali, R.: An Empirical Study for Implementation of Lean Principles in Indian Manufacturing Industry. Benchmarking: An International Journal 23(1), 183-207 (2016)

4. Modrak, V., Marton, D., Bednar, S.: The Influence of Mass Customization Strategy on Configuration Complexity of Assembly Systems. Procedia CIRP 33, 539-544 (2015)

5. Slack, N.: The Flexibility of Manufacturing Systems. International Journal of Operations \& Production Management 25(12), 1190-1200 (2005)

6. MacCormack, A., Verganti, R., Iansiti, M.: Developing Products on "Internet time": The Anatomy of a Flexible Development Process. Management science 47(1), 133-150 (2001)

7. Baykasoglu, A., Ozbakir, L.: Analysing the Effect of Flexibility on Manufacturing Systems Performance. Journal of Manufacturing Technology Management 19(2), 172-193 (2008)

8. Boyle, T.A.: Towards best Management Practices for Implementing Manufacturing Flexibility. Journal of Manufacturing Technology Management 17(1), 6-21 (2006)

9. Chang, S.C., Lin, R.J., Chang, F.J., Chen, R.H.: Achieving Manufacturing Flexibility Through Entrepreneurial Orientation. Industrial Management \& Data Systems 107(7), 997-1017 (2007)

10. Wahab, M., Wu, D., Lee, C.G.: A Generic Approach to Measuring the Machine Flexibility of Manufacturing Systems. European Journal of Operational Research 186(1), 137-149 (2008)

11. Holweg, M.: The Genealogy of Lean Production. Journal of operations management 25(2), 420-437 (2007)

12. Baines, T., Lightfoot, H., Williams, G.M., Greenough, R.: State-of-the-art in Lean Design Engineering: A Literature Review on White Collar Lean. Proceedings of the Institution of Mechanical Engineers, Part B: Journal of Engineering Manufacture 220(9), 1539-1547 (2006)

13. Qudrat-Ullah, H., Seong, B.S., Mills, B.L.: Improving High Variable-low Volume Operations: An Exploration Into the Lean Product Development. International Journal of Technology Management 57(1/2/3), 49-70 (2012)

14. Gupta, D., Buzacott, J.A.: A Framework for Understanding Flexibility of Manufacturing Systems. Journal of manufacturing systems 8(2), 89-97 (1989)

15. Kara, S., Kayis, B.: Manufacturing Flexibility and Variability: An Overview. Journal of Manufacturing Technology Management 15(6), 466-478 (2004)

16. Agarwal, A., Shankar, R., Tiwari, M.: Modeling the Metrics of Lean, Agile and Leagile Supply Chain: An ANP-Based Approach. European Journal of Operational Research 173(1), 211-225 (2006)

17. Boynton, A.C., Victor, B., Pine II, B.J.: New Competitive Strategies: Challenges to Organizations and Information Technology. IBM systems journal 32(1), 40 (1993)

18. Smith, S., Smith, G.C., Jiao, R., Chu, C.H.: Mass Customization in the Product Life Cycle. Journal of Intelligent Manufacturing 24(5), 877-885 (2013)

19. Harker, P.T.: Incomplete Pairwise Comparisons in the Analytic Hierarchy Process. Mathematical Modelling 9(11), 837-848 (1987)

20. Nascimento, L.d.O.: Fatores que Influenciam a Flexibilidade da Produção de Veículos Comerciais (2016) 